\title{
Effectiveness of Active Debate Method in English Speaking Skills of Students in SMAN 3 Padangsidimpuan
}

\author{
Khairunnisah ${ }^{1 *}$, Apriyanti Hasibuan², Happy Sri Rezeki Purba ${ }^{3}$ \\ ${ }^{1,2,3}$ Department of English, Universitas Muhammadiyah Tapanuli Selatan, Indonesia
}

\begin{tabular}{l|l|l|l|}
\hline Contact: & Khairunnisa & khairunnisah@um-tapsel.ac.id
\end{tabular}

\begin{abstract}
This research aimed were :1) Knowing the effectiveness of the debate method in improving students' speaking skills in learning English, 2) Knowing the differences in students' speaking skills using the debate method and without using debate method. The data were collected using test, they were pretest and posttest. The result of evaluation was analyzed through quantitative. The results showed: There was a significant difference between the speaking skills of students who received speaking learning using the active debate method with students who received speaking learning without using the active debate method. The difference in speaking skills was indicated by the results of the posttest t-test of the control group and the posttest of the experimental group, namely the calculation results show that the $t$ count score was greater than the t table score (th: 2.882> tt: 1.994) at the $5 \%$ significance level and $\mathrm{db} 70$. The results of the t-test showed that there were differences in the speaking skills of the control group students who received speaking learning without using the active debate method and the experimental group that received speaking learning using the active debate method.
\end{abstract}

\section{KEYWORDS:}

Speaking skill; Effectiveness; Active debate method.

\section{Introduction}

Speaking is a process of communication with other people. Through speaking,

a person can convey his wants and needs to others. When speaking, the speaker must say or convey his message clearly so that others understand. In term of spoken language, speaking has a main role in delivering messages or ideas which has different features from the written language which could be seen from voice qualities, facial expressions, gestures, intonation, pronunciation, stress, rhythm and pausing (Wahyuningsih, 2018, p. 82). Besides, there are crucial aspects needed in speaking skills including social and cultural 
rules which deal with the strategies of doing turn-taking, participants' roles, and circumstances (Wahyuningsih $\&$ Dewi, 2019, p. 2).

Referring to it, someone who is not able to speak in public often experiences depressed symptoms which consist of physical, mental, and mental processes. Physical symptoms cover 1 ) an increasingly rapid heartbeat, 2) a vibrating sound that is often accompanied by straining the throat muscles or the accumulation of mucus in the throat, and 3) hyperventilation including difficulty breathing. Symptoms that include mental processes include: 1) repeating words, sentences, or messages, 2) memory loss, including the inability of the speaker to remember facts or numbers correctly, and forgetting things that are very important, and 3) clogging of the mind that makes the speaker does not know what to say next. While those that include physical and mental symptoms are fear, feeling of inadequacy, feeling of loss of control, feeling helpless, shame, and panic.

In learning English, students must be able to speak English and the main aim for students to study English is communicate using English. In reality, there were many students still lack in speaking skill. Likewise, the problems were faced by students in State High School 3, especially class $X$, they were still hesitant and even afraid to expressed their opinions or speak by using English. This happened because of a lack of training to improve students' skills in speaking English. Speaking skills should be trained continuously and gradually. Teachers should also condition learning so students have the opportunity to communicate using English. One method of learning that can apply the contextual approach to contextual learning through debate.

A number of studies related to speaking skills have been undertaken by some previous researchers. Nikmah (2018, p. 2) has developed speaking materials using Islamic contents for students. Likewise, Setyawati $(2018$, p. 13) has developed "CH-CD Electrolyte Solution Test Tools" for teaching spoken procedure text to twelfth graders of senior high school. More specifically, Pradana (2017, p. 2) has used English Debate to enhance student's speaking 
ability and build character building which can be considered as building confidence among the students. In line with it, Iman (2017, p. 87) has improved debate instructions to foster students' speaking ability and critical thinking skills. The result of his study indicates that there was a significant improvement in critical thinking and speaking skill after using debate instruction in EFL classroom. Likewise, this study more emphasizes the effectiveness of active debate method in English speaking skills among students in SMAN 3 Padangsidimpuan.

\section{Method}

The approach used in this study is a quantitative approach, because research data in the form of numbers and analysis using statistics. The research method used in this study is a quasi-experimental method that is used to find the effect of certain treatments on others under controlled conditions. The treatment in question is the application of the debate method in the discussion learning of class X students of Padangsidimpuan 3 High School.

This study uses a pretest posttest design control group research design (Arikunto, 2006, p. 86). The design is described as follows.

Table 1. Design pretest and posttest

\begin{tabular}{cccc}
\hline Group & Pretest & Experiment & Postest \\
\hline $\mathrm{E}$ & 01 & $\mathrm{x}$ & 02 \\
\hline $\mathrm{K}$ & 03 & - & 04 \\
\hline
\end{tabular}

Note:

E : Experimental Group

$\mathrm{K}$ : Control Group

01 : Pretest Group Experiment

02 : Posttest Group Experiment

03 : Pretest Group Control

04 : Posttest Group control

$X$ : Speaking learning by using active debate method 


\section{Research paradigm}

Research paradigm is a mindset that shows the relationship between variables studied while reflecting the type and number of problems that need to be answered through research(Sugiyono, 2009, p. 66). In addition, the research paradigm is a relationship model between variables in a research activity.

The prescribed research variables were subjected to prauji by measuring the pretest. The treatment in the experimental group used the debate method, while the control group did not use the debate method. After that, the experimental group and the control group were subjected to measurements using the posttest measurement. The paradigm is shown in the picture as follow.

a. Experimental Group Paradigm

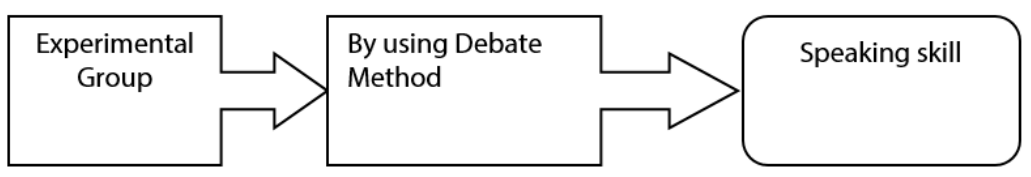

b. Control Group Paradigm|

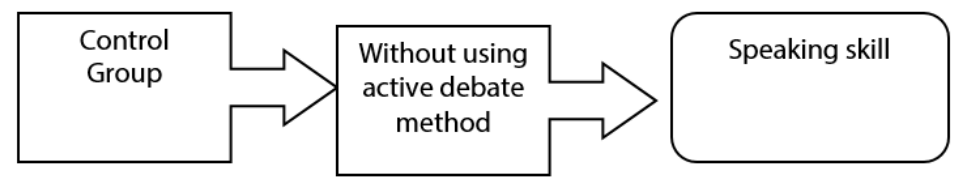

Figure 1. The research paradigm

\section{Population and Sample}

This research was conducted at JL. Perintis Kemerdekaan No: 56, Padangmatinggi, Kec. Padang Sidimpuan Selatan, Padangsidimpuan City. This study lasted for 3 months.The population of this study was selected students of class $X$ of SMA Negeri 3 Padangsidimpuan. The total population of class $X$ Padangsidimpuan 3 Senior High School is 396 students, with details of classes $X 1, X 2, X 3, X 4, X 5, X 6, X 7, X 8, X 9, X 10, X 11$, each of which 36 students. The sampling technique uses probability sampling techniques. This technique provides equal opportunities for each element (member) of the population to be chosen as members of the sample (Sugiyono, 2009). Sampling is done in a 
simple way that is randomly without paying attention to the strata in the population. This type of probability sampling is called simple random sampling.

Random sampling is done by raffling all class $X$, which amounts to 7 classes. The seven classes were drawn to determine the class subjected to treatment (experimental class) and the class to be designated as the control class. The two classes of the first lottery results were drawn back to determine the experimental class and the control class. Based on the results of the draw, students of class X MIA 1 are determined as the experimental class, while class $X$ MIA2 is defined as the control class. The number of samples in this study amounted to 72 students.

\section{Instrument}

The research instrument is a tool used to measure natural and social phenomena observed. Specifically all of these phenomena are called research variables (Sugiyono, 2009). The research instrument used was a test. The initial test was conducted to determine students' speaking skills before being treated. The final test was conducted to find out students' speaking skills after being treated. This test is carried out before being given treatment (pretest) and after being treated (posttest) for both the experimental group and the control group. Students will get scores from tests conducted before and after treatment. This score is collected as an analysis material.

According to (Nurgiyantoro, 2001, p. 289) the scale that can be used to measure discussion is the model $0-10$ or $1-10$. However, in this study the scaling scale was modified to 1-4. This is intended to facilitate scoring because the criteria for the aspects assessed are shorter and clearer. The following is a grid of research instruments that will be used as guidelines for assessing speaking skills. This guideline is based on the criteria for supporting factors of speaking effectiveness proposed by Maidar (Arsjad, 1988, pp. 17-22), also according to (Nurgiyantoro, 2001).This test is given in order to determine the level of students' abilities in the discussion through the debate method. Scaling scale used to measure students' speaking skills is given a range of values from the 
highest to the lowest. The highest score is 4 and the lowest is 1 , but if there are students who do not give opinions, objections or questions are given a score of 0 . Then the range of categories is very good, up, enough, and less. Scores between 3-4 are expressed in excellent categories, scores between 2-3 are expressed in good categories, scores between 1-2 are expressed in sufficient categories, and scores between 0-1 are expressed in less categories.

Table 2. Guidelines for Assessing Student Speaking Skills

\begin{tabular}{|c|c|c|c|c|c|}
\hline \multirow{2}{*}{ No } & \multirow{2}{*}{ Aspek } & \multicolumn{3}{|c|}{ Skala skor } & \multirow[t]{2}{*}{ Jumlah } \\
\hline & & 4 & 3 & 2 & \\
\hline 1 & Giving opinion & & & & \\
\hline 2 & Accepting opinion & & & & \\
\hline 3 & Ability to maintain opinion & & & & \\
\hline 4 & Speaking fluently & & & & \\
\hline 5 & Speaking clearly & & & & \\
\hline 6 & Structure and vocabulary & & & & \\
\hline 7 & Speaking bravery & & & & \\
\hline 8 & Responding & & & & \\
\hline 9 & Eyes contact & & & & \\
\hline 10 & Topic mastery & & & & \\
\hline
\end{tabular}

The observation component of the debate is as follows:

Table 3. Guidelines for Assessing Student by using debate method

\begin{tabular}{lllll}
\hline & \multirow{2}{*}{ Aspek } & \multicolumn{2}{c}{ Skala Tindakan } & Jumlah \\
\cline { 3 - 4 } & & $\mathbf{1}$ & $\mathbf{2}$ & $\mathbf{3}$ \\
\hline 1. & Topic mastery & & \\
\hline 2. & thinking logically & \\
\hline 3. & argument & \\
\hline 4. & giving opinion clearly & \\
\hline
\end{tabular}

\section{Data analysis}

The research instrument is a tool used to measure natural and social phenomena observed. Specifically all of these phenomena are called research variables (Sugiyono, 2009). The research instrument used was a test. The initial test was conducted to determine students' speaking skills before being treated. The final test was conducted to find out students' speaking skills after being treated. This test is carried out before being given treatment (pretest) and after being treated (posttest) for both the experimental group and the control group. Students will get scores from tests conducted before and after treatment. This score is collected as an analysis material. 
According to (Nurgiyantoro, 2001) the scale that can be used to measure discussion is the model $0-10$ or $1-10$. However, in this study the scaling scale was modified to 1-4. This is intended to facilitate scoring because the criteria for the aspects assessed are shorter and clearer. The following is a grid of research instruments that will be used as guidelines for assessing speaking skills. This guideline is based on the criteria for supporting factors of speaking effectiveness proposed by Maidar (Arsjad, 1988), also according to (Nurgiyantoro, 2001). This test is given in order to determine the level of students' abilities in the discussion through the debate method.

Scaling scale used to measure students' speaking skills is given a range of values from the highest to the lowest. The highest score is 4 and the lowest is 1 , but if there are students who do not give opinions, objections or questions are given a score of 0 . Then the range of categories is very good, up, enough, and less. Scores between 3-4 are expressed in excellent categories, scores between 2-3 are expressed in good categories, scores between 1-2 are expressed in sufficient categories, scores between 0-1 are expressed in less categories.

$$
I=\frac{r-\text { tvalue }}{-d f} x(d f-\text { lowest } d-)
$$

I: interpolation value

$r$-t value: range (difference) value of $t$ in table of two d.k. the closest

r-df: range (difference) from two d.k. the closest

\section{Data Analysis Requirements}

In the use of the t-test, there must be analysis terms in the form of distribution normality test and variance homogeneity test.

\section{Test for Distribution Normality}

Distribution normality test aims to test the normal distribution of research data. This test uses the Kolmogorov Smirnov statistical technique. In this study, the distribution normality test was carried out on the pretest and posttest scores 
on the experimental group and the control group. The calculation process in this study was assisted by the SPSS 17.0 program.

Interpretation of the results of the normality test by looking at the sig value. (2-tailed). The interpretation of the normality test is as follows.

1. If the value is sig. (2-tailed) greater than the alpha level 5\% (sig. (2tailed) $>0.050$, it can be concluded that the data comes from populations whose distribution is normally distributed.

2. If the value is sig. (2-tailed) smaller than alpha level 5\% (sig. (2-tailed) $<0.050$ ), it can be concluded that the data deviates or is abnormally distributed.

\section{Variant Homogeneity Test}

The variance homogeneity test aims to determine whether the samples taken from the population have the same variant and do not show significant differences with each other. According to Burhan (Nurgiyantoro, 2001), to test the variance homogeneity it is necessary to do statistical tests on the distributor scores of the groups concerned. Testing the scores of the groups concerned is carried out using the SPSS 17.0 program. This homogeneity can be seen from the test results of the variance homogeneity of statistical levene. If the significance is greater than 0.050 , the score of the test results has no variance or homogeneous differences.

\section{Statistical Hypothesis}

The statistical hypothesis is also called the null hypothesis $(\mathrm{Ho})$. This hypothesis states that there is no difference between two variables or no effect of variable $X$ on variable $Y$. Below is the formulation of the hypothesis in the study.

1. Ho: $\mu 1=\mu 2$

Ha: $\mu 1 \neq \mu 2$

Ho: There was no difference in speaking skills between the groups that received learning to speak English using the debate method and the group that received learning spoke English without using the debate method. 
Ha: There is a difference in speaking skills between groups that receive learning to speak English using the debate method and groups that receive learning speak English without using the debate method.

\section{Result}

This study aims to determine the differences in discussion skills between students in class $X$ of SMA Negeri 3 Padangsidimpuan who learned speaking skills using the active debate method and the speaking skills of students who received speech learning without using active debate methods. In addition, this study also aims to determine the effectiveness of the active debate method in the speaking skills of class X Padangsidimpuan 3 Senior High School students. The data in this study included data on the initial test score (pretest) and the final test score (posttest) of speaking skills. Data from the initial test scores were obtained from the scores of the results of the pretest of students 'speaking skills and the final test score data obtained from the scores of the posttest results of students' speaking skills. The results of the research in the control group and experimental group are presented as follows.

\section{Pretest Control Group in Speaking Skills}

Class X MIA1 is a control group that gets learning speaking skills without using active debate methods. Before the control group was treated, the pretest of speaking skills was carried out first, namely in the form of a speaking test. Subjects at the pretest of the control group were 36 students. From the results of the initial test (pretest) speaking skills, the highest score achieved by students is 26 and the lowest score is 0.

The following is the presentation of the frequency distribution of the pretest skills in speaking skills control group. 
Table 4. Frequency Distribution of Pretest Scores Control Group Speaking Skills

\begin{tabular}{llllll}
\hline No & Interval & Frequency & $\begin{array}{l}\text { Frequency } \\
(\%)\end{array}$ & $\begin{array}{l}\text { Cumulative } \\
\text { Frequency }\end{array}$ & $\begin{array}{l}\text { Cumulative } \\
\text { Frequency } \\
(\%)\end{array}$ \\
\hline 1 & $0-3$ & 8 & 22,22 & 12 & 33,33 \\
\hline 2 & $4-7$ & 4 & 11,11 & 17 & 47,22 \\
\hline 3 & $8-11$ & 5 & 13,88 & 22 & 61,11 \\
\hline 4 & $12-15$ & 5 & 13,88 & 33 & 91,66 \\
\hline 5 & $16-19$ & 11 & 30,55 & 34 & 94,44 \\
\hline 6 & $20-23$ & 1 & 2,77 & 35 & 97,22 \\
\hline 7 & $24-27$ & 1 & 2,77 & 36 & 100 \\
\hline
\end{tabular}

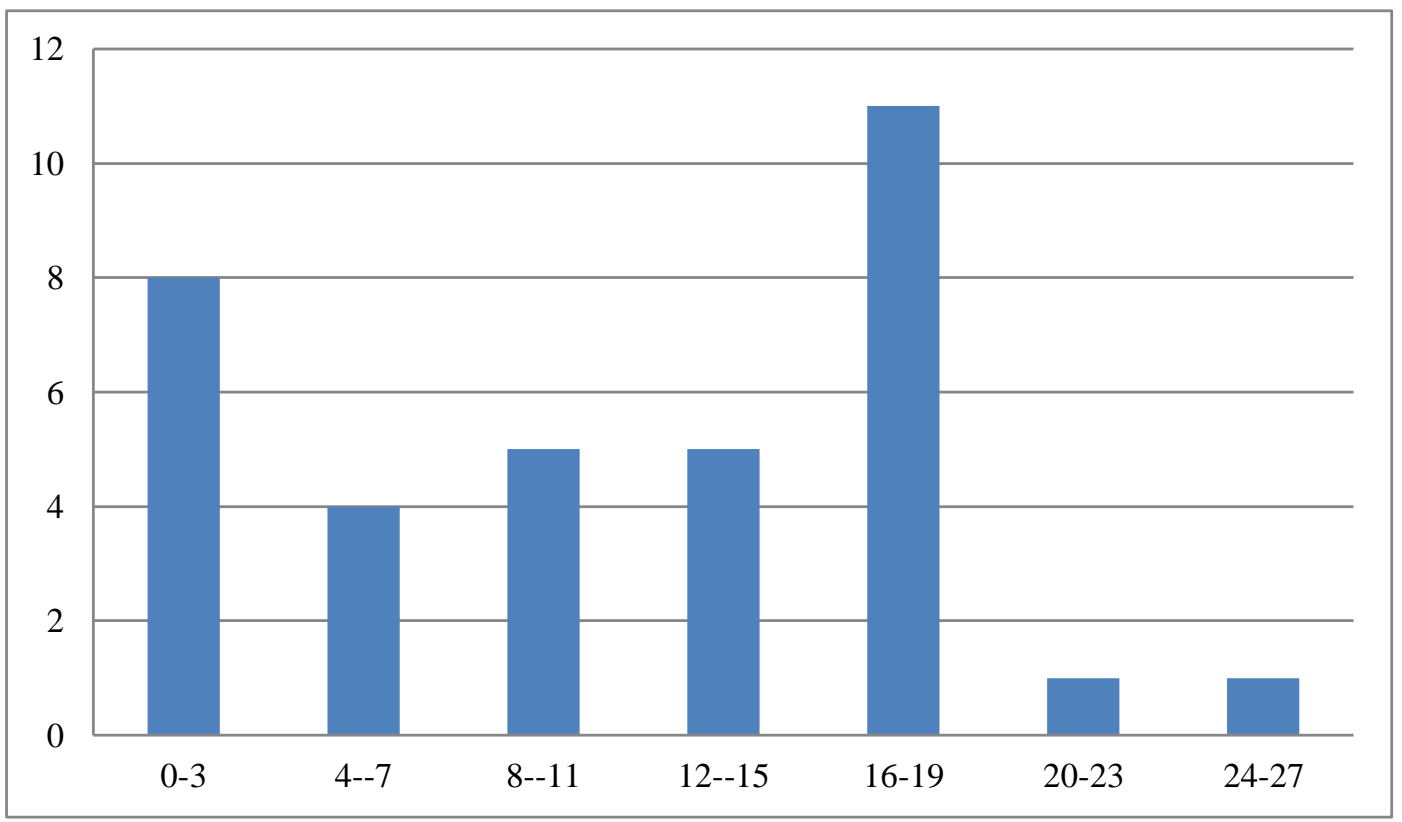

Figure 2. Distribution frecuency of Pretest Scores Control Group Speaking Skills

Table 5. Summary of Statistical Data Pretest Speech Skills ScoreControl group

\begin{tabular}{lllllllll}
\hline No & Data & N & High Score & Low Score & $\bar{X}$ & Md & Mo & SD \\
\hline 1. & $\begin{array}{l}\text { Pretest kelompok } \\
\text { Kontrol }\end{array}$ & 36 & 26 & 0 & 11.22 & 12.50 & 0 & 7.669 \\
\hline
\end{tabular}

\section{Pretest Speaking Skills in Experimental Groups}

Class X MIA 2 is an experimental group that got speaking skills using active debate methods. Before the experimental group was treated, the pretest of speaking skills was first performed, namely in the form of a speaking test. Subjects at the pretest of the experimental group were 36 students. From the 
results of the initial test (pretest) speaking skills, the highest score achieved by students is 28 and the lowest score is 0.

Table 6. Frequency Distribution of Pretest Scores Group Speaking Skills Experiment

\begin{tabular}{cccccc}
\hline No & Interval & Frekuensi & $\begin{array}{c}\text { Frekuensi } \\
(\%)\end{array}$ & $\begin{array}{c}\text { Frekuensi } \\
\text { Kumulatif }\end{array}$ & $\begin{array}{c}\text { Frekuensi } \\
\text { Kumulatif } \\
\text { (\%) }\end{array}$ \\
\hline 1 & $0-5$ & 8 & 22.22 & 8 & 22.22 \\
\hline 2 & $6-10$ & 11 & 30.55 & 19 & 52.77 \\
\hline 3 & $11-15$ & 5 & 13.88 & 24 & 66.66 \\
\hline 4 & $16-20$ & 9 & 25 & 33 & 91.66 \\
\hline 5 & $21-25$ & 0 & 0 & 33 & 91.66 \\
\hline 6 & $26-30$ & 3 & 8.33 & 36 & 100 \\
\hline
\end{tabular}

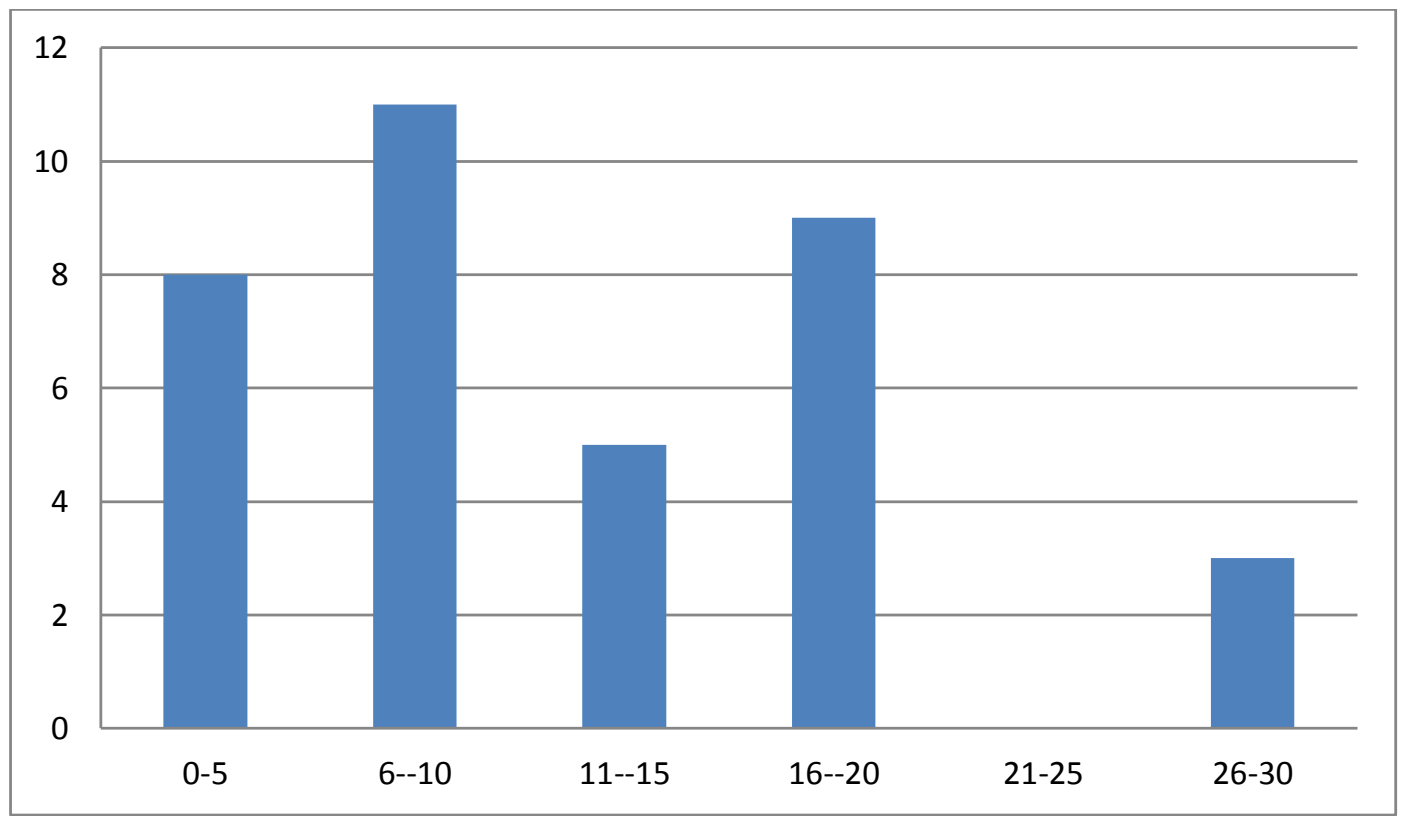

Figure 3. Frequency Distribution of Pretest Scores Group Speaking Skills Experiment

Table 7. Summary of Statistical Data Pretest Score of Experimental Group Speaking Skills

\begin{tabular}{ccccccccc}
\hline No & Data & N & $\begin{array}{c}\text { Skor } \\
\text { tertinggi }\end{array}$ & $\begin{array}{c}\text { Skor } \\
\text { terendah }\end{array}$ & $\bar{X}$ & Md & Mo & SD \\
\hline 1. & $\begin{array}{c}\text { Pretest kelompok } \\
\text { Kontrol }\end{array}$ & 36 & 28 & 0 & 11.28 & 10.00 & 0 & 7.952 \\
\hline
\end{tabular}

\section{Posttest of Control Group Speech Skills}

The posttest of speaking skills in the control group was intended to see the achievement of the remaining speaking skills of those who received speech 
learning without using the active debate method. From the final results of the speaking skills, the highest score achieved was 27 and the lowest score was 0.

The following is a summary of the results of the control group postets data processing.

Table 7: Summary of Statistical Data Score Postest Speech SkillsControl group

\begin{tabular}{ccccccccc}
\hline No & Data & N & $\begin{array}{c}\text { High } \\
\text { score }\end{array}$ & Low score & $\bar{X}$ & Md & Mo & SD \\
\hline 1. & $\begin{array}{c}\text { Pretest control } \\
\text { group }\end{array}$ & 36 & 27 & 0 & 12.28 & 13.50 & 0 & 7.520 \\
\hline
\end{tabular}

\section{Postest Speaking Skills in Experimental Groups}

Class X MIA 2 is an experimental group that gets speaking skills using active debate methods. After being given a pretest and given a teaching method with an active debate method, then to find out the influence of the active debate method in students' speaking skills by giving posttest. The value for the posttest obtained can be seen from the following table.The following is a summary of the results of the posttest data processing of the experimental group.

Table 8. Summary of Statistical Data Score Postest Speech Group Experimental Skills

\begin{tabular}{lllllllll}
\hline No & \multicolumn{1}{c}{ Data } & N & High score & Low score & $\bar{X}$ & Md & Mo & SD \\
\hline 1. & $\begin{array}{l}\text { Postest experimental } \\
\text { group }\end{array}$ & 36 & 33 & 0 & 17.11 & 15.50 & 01 & 6.688 \\
\hline
\end{tabular}

\section{Normality Test Data distribution}

This distribution normality test data was obtained from the pretest and posttest speaking skills, both the control group and the experimental group. A requirement for data is normally distributed if the $P$ value obtained from the calculation results is greater than 0.05 (5\% significance level). All calculations using SPSS 17.0 help produced the Sig. (2-tailed). The series of results of the normality of the data distribution test speaking skills of the control group and experimental group are presented as follows. 
Table 9. Summary of Normality Test Results Speech Data Distribution.

\begin{tabular}{ccl}
\hline Data & Asymp. Sig. (2-tailed) & \multicolumn{1}{c}{ Note } \\
\hline Pretest kelas kontrol & 0,106 & Asymp. Sig. (2-tailed) $>0,05=$ normal \\
\hline Pretest kelas ekperimen & 0,200 & Asymp. Sig. (2-tailed) $>0,05=$ normal \\
\hline Postest kelas kontrol & 0,100 & Asymp. Sig. (2-tailed) $>0,05=$ normal \\
\hline Postest kelas ekperimen & 0,179 & Asymp. Sig. (2-tailed) $>0,05=$ normal \\
\hline
\end{tabular}

The results of calculating the distribution normality test are known as Asymp. Sig. (2-tailed) greater than 0.05 , it can be concluded that the distribution of pretest and posttest data on speaking skills of the control group and experimental group were normally distributed.

\section{Test of Variance Homogeneity}

After testing the data distribution normality, then the variance homogeneity test was carried out with the help of SPSS version 17.0. The requirement is that the variant is homogeneous if the calculated significance value is greater than the specified significance level, which is $5 \%(0.05)$. The summary results of the variance homogeneity test data pretest and posttest speaking skills are presented as follows.

Table 10. Summary of Homogeneity Test Results for Pretest and Posttest Variants of Speaking Skills

\begin{tabular}{ccccc}
\hline Data & Levene statistik & Db & Sig. & Note \\
\hline Pretest & 0,032 & 70 & 0,859 & Sig. $0,859>0,05$ \\
\hline Postest & 0,673 & 70 & 0,415 & Sig. $0,415>0,05$ \\
\hline
\end{tabular}

The results of the pretest variant homogeneity test calculation showed that the score of Levene's test results was 0.032 and $d b 70$, and the significance of 0 , 859. Because the significance was greater than $0.05(5 \%)$, the data pretest of speaking skills had variants that homogeneous or has no variant differences. The results of the posttest variance homogeneity test calculation can be seen that Levene's test score is 0,673 and $d b \quad 70$, and the significance of 0.415 . Because the significance is greater than $0.05(5 \%)$, the posttest data of the speaking skills in this study have a homogeneous variant or no variant differences. 


\section{Discussion}

Based on the analysis of the research data, the effectiveness of active debate method to improve students' speaking skill in grade $X$ of students SMA Negeri 3 Padangsidimpuan showed that was very effective to use. The data got from the results of value the tests performed during the process of research. The comparison value looks very different between class control and class experimental. This research used pretest and posttest to know the students's score in learning speaking by using active debate method and also without using debate method. Based on some of the impacts that arised by using active debate method in speaking skill could be known that by using appropriate media and methods in learning process in the classroom can overcome a variety of obstacles appeared and experienced both by teachers and learners in schools. The role of teachers is very important as a determinant of the initial success of the learning process and the results obtained by the wish of both parties.

Debate method can be extended to cope with the boredom of students in learning in the classroom by using appropriate strategies notably in helping students speaking fluently. Developing more attractive media, interesting, and challenging nature is more delighted by students than medium and the monotonous method. More students feel free expression and arguing because at that age the growth of student's curiosity more precedence than just imitate what has been described the teacher of teachers. Teachers more objective acts as a facilitator with the activities of the students in the class. However, teachers also do not necessarily let students act anything that does not fit the naturalness of the students at the school. When students have to feel comfortable in learning of a teaching material, then automatically the results to be achieved can be obtained easily. This debate method is not ending of the development method in teaching and learning speaking. Another form of methods can also be taken to provide an advanced research to make speaking 
English easier and understable by students from the basic level until higher level.

\section{Conclusion}

Based on the results of the research and discussion that has been submitted previously, the conclusion can be taken as follows. There was a significant difference between the speaking skills of students who received speaking learning using the active debate method with students who received speaking learning without using the active debate method in class X Padangsidimpuan 3 Senior High School students. The difference in speaking skills is indicated by the results of the posttest t-test of the control group and the posttest of the experimental group, namely the calculation results show that the t count score is greater than the t table score (th: 2.882> tt: 1.994) at the $5 \%$ significance level and $\mathrm{db} 70$. The results of the t-test showed that there were differences in the speaking skills of the control group students who received speaking learning without using the active debate method and the experimental group that received speaking learning using the active debate method.

This research is limited to the classrooms used for implementation research. The method used in this study is the active debate method a sitting position need set the table and chairs faced to face. This causes every time you will do learning arrange according to the sitting position offered in the active debate method. However, given the large number of students which is 36 students so the position neither can sitting completely like the procedure offered in this debate method. In addition, this research was conducted only in one school where class that is used as a control group and an experimental group on one environment. Possibility between control group and group the experiments do quite large interactions. However, this is not the case cause bias because this research is related to speaking skills especially English. Even though groups interact, they don't give effect to the time of treatment as well as the final test results. 


\section{References}

Arikunto, S. (2006). Prosedur Penelitian Suatu Pendidikan Praktik. Yogyakarta: Rineka Cipta.

Arsjad, M. G. (1988). Pembinaan Kemampuan Berbicara Bahasa Indonesia. J akarta: Erlangga.

Iman, J. N. (2017). Debate instruction in EFL classroom: Impacts on the critical thinking and speaking skill. International J ournal of Instruction, 10(4), 87-108. https://doi.org/10.12973/iji.2017.1046a

Nikmah, A. (2018). Developing Speaking Material Using Islamic Contents in MA Salafiyah Kajen. J ournal of English Teaching and Learning Issues, 1(1), 1-12.

Nurgiyantoro, B. (2001). Penilaian dalam Pengajaran Bahasa dan Sastra. Yogyakarta: BPFE.

Pradana, S. A. (2017). Using Debate to Enhance Students' Speaking Ability As Their Character Building. English Education: J urnal Tadris Bahasa Inggris, 10(1), 149-163. Retrieved from

http://ejournal.radenintan.ac.id/index.php/ENGEDU/article/view/881

Setyawati, E. (2018). Developing "CH-CD Electrolyte Solution Test Tools" Game for Teaching Spoken Procedure Text to Twelfth Graders of Senior High School. J ournal of English Teaching and Learning Issues, 1(1), 13-28.

Sugiyono, S. (2009). Memahami Penelitian Kualitatif. Bandung: Alfabeta.

Wahyuningsih, S. (2018). The Use of Video to Enhance Speaking Proficiency in Broadcasting: Perceptions of Undergraduate Students. International Conference on Linguistics.

Wahyuningsih, S., \& Dewi, S. (2019). Promoting Speaking Proficiency in Broadcasting Through YouTube Project: Perceptions of Undergraduate Students. Proceedings of Third English Language and Literature International Conference, 1-7. https://doi.org/10.4108/eai.27-4-2019.2285332 